\title{
Snow flakes and fates: what hope is there for Alpine winter tourism?
}

\author{
A. Fischer \\ Institute of Interdisciplinary Mountain Research, \\ Austrian Academy of Sciences, Austria
}

\begin{abstract}
The rapid development of Alpine winter tourism and related infrastructures during the last century raises the question of development prospects against the background of climate change and sustainability. Today, amongst other macroscale forcings, snow is considered a precondition for winter tourism. The aim of this study is to investigate past climate change for four communities in Tyrol in relation to the number of overnight stays, and to compare the variability of the current climate with the bandwidth of future scenarios. This is done by analysing i) trends of air temperature, humidity and snow and ii) the statistical correlation of these parameters with the number of overnight stays. The height and duration of natural snow cover show high interannual variability. As a technical response, snow production has developed rapidly. Applying a Mann-Kendall test to the wet-bulb temperatures recorded at three Tyrolean climate stations reveals that the time frames when snow production is possible have changed most at medium elevations, but have so far not exceeded a few days at the beginning and the end of the winter season. In contrast to summer mean temperatures, winter mean temperatures have not changed significantly during the last 3 decades, and the range of interannual variability was about three times that of the most extreme temperature change calculated for future climate scenarios. Therefore it is very likely that the average future winter climate means will be within the range of the past century's records, and snow cover and temperature changes are minor macroscale forcings, so they are not factors that would delimit the future developments of Alpine winter tourism.
\end{abstract}

Keywords: climate change, winter tourism, snow production, ski tourism, snow cover. 


\section{Introduction}

After several thousand years of settlement history, the Alpine environment experienced its most significant changes in physical and human terms since the mid- $19^{\text {th }}$ century. The development of transport infrastructures and the transition from an agrarian society to a modern society left its traces not only by changing the landscape in the course of changing modes of land use, but also imprinted themselves on Alpine sociocultural and economical structures. These global changes coincided with climate warming after the Little Ice Age, which had made life difficult for the Alpine agricultural society for several hundred years, up to the glacial maximum observed around 1850 .

With the development of roads and railroad connections, the increasing number of tourists, more and more physical and organizational tourist infrastructure developed, e.g. cable cars and travel agencies.

Today, tourism contributes 5.8\% to the GDP [1], a significant share of the Austrian economy. If one includes indirect effects, these are estimated to be about three times the size of the direct effects [2]. Regionally and locally, the relative importance of tourism can be even higher, especially in peripheral, small mountain villages 'at the end of the roads', where other earnings are scarce and difficult to develop under a global trend to urbanization.

The macroscale drivers of tourism identified by Scott and Lemieux [3] include the economic situation, transport, political stability, technological and demographic change, exchange rates, travel limitations and climate change. As an additional factor, the amount of spare time can be considered. The rapid growth of the Alpine tourism industry within the last two centuries triggered the question of the limits of its growth, together with many centuries of discussions about the ecological, sociocultural and economic impacts and drivers.

In recent decades, a variety of concepts for sustainable tourism have been developed [4]. The World Tourism Organisation [5] defined sustainable tourism as tourism 'which meets the need of present tourists and host regions while protecting and enhancing opportunity for the future'. As this definition meets Heinz von Förster's ethical imperative [6] of increasing future possibilities, we will stick to this definition in this study.

Currently, and alongside socioeconomic, ecological and cultural impacts, the limitations of a sustainable development of tourism through climatic change are being discussed. Often, winter tourism is claimed as prime example for the climate sensitivity of tourism, although very different opinions exist on its role for sustainability [7, 8]. While first studies focused on the reliability of natural snow cover [9], more recent studies pay increasing attention to snow production as an adaption strategy to climate change [10]. Future perspective planning, including climate [11] and socioeconomic [12,13] changes, and transition management [14] is often done using scenario analysis [15].

This study aims at sketching the status quo and recent developments in Tyrolean winter tourism together with the development of population, transportation capacities, and climatic parameters. Investigated climatic parameters are snow cover, snow production times derived from time series of 
air temperatures and humidity. This retrospective part of the study addresses the question if winter tourism in the past was correlated or causally related to climatological parameters. This is an important question for the development of future strategies. If no correlation between climate and tourism development can be found, there is no empirical evidence for an instantaneous appearance of such a relationship. This implies that the investigated data from the past cover most system statuses likely to occur in future. Therefore, the variability of the past system is compared to future climate scenarios, assuming that in a changing climate the absolute frequency of specific system statuses changes, so that the mean system status changes, whereas extreme events remain extreme events in a changed climate.

\section{Status quo: winter tourism in Tyrol}

In Northern Tyrol, 84 ski resorts have been operating (Figure 1) at altitudes between $460 \mathrm{~m}$ and $3,400 \mathrm{~m}$ a.s.1. $64 \%$ of the total ski resort area is located at altitudes between 1,200 $\mathrm{m}$ and 2,400 $\mathrm{m}$ a.sl., 9\% below $900 \mathrm{~m}$ and $10 \%$ above 2,500 $\mathrm{m}$ a.s.1. Four communities representing different types have been selected for detailed investigations. The village of Neustift is located at the end of the Stubai valley, Schönberg at the entrance of the same valley, close to the city of Innsbruck. The villages of Ischgl and Galtür are located in the upper Paznaun valley, a rather peripheral area at the end of the Paznaun valley. The proportion of total area to permanent settlement area differs between these communities as does the share of ski resort area (Table 1).

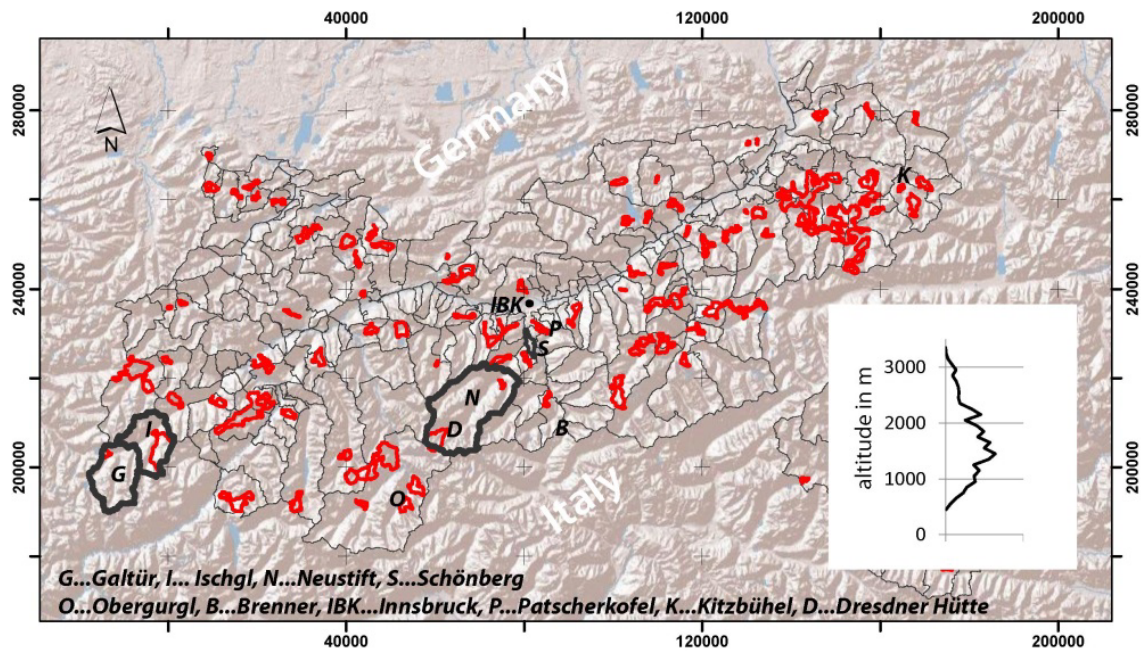

Figure 1: Map of the province of Tyrol, ski resorts as defined by official spatial planning figures (red) and climate stations used in this study. The distribution of the ski resorts across the altitudinal range is shown in the insert. 
The small community of Schönberg has no ski resort, and about one third of the area is permanent settlement area. In the three other communities, only a few percent of the area falls into that category. In Neustift and Galtür, less than $1 \%$ of the total area is used as ski resort, whereas Ischgl uses more than $3 \%$ of its area for skiing.

Table 1: $\quad$ Percentage of the total municipal and provincial area available for permanent settlements and used for ski resorts.

\begin{tabular}{|l|c|c|}
\hline & \multicolumn{2}{|c|}{ Proportion of the total area } \\
\hline Municipality & Ski & Permanent \\
\hline Neustift/Stubaital & 0.5 & 4.1 \\
\hline Schönberg/Stubaital & 0.0 & 32.1 \\
\hline Galtür & 0.4 & 2.7 \\
\hline Ischgl & 3.4 & 4.3 \\
\hline Tyrol & 0.6 & 12.4 \\
\hline
\end{tabular}

After the Second World War rapid population growth set in (Figure 2). Today Galtür has the lowest number of inhabitants and the weakest growth, whereas Schönberg is subject to amenity migration from the nearby city of Innsbruck. The highest population growth is found in Neustift. All trends flatten in the last decade. The number of cable cars has been increasing by about $50 \%$ to $100 \%$ since the 1970s in Galtür, Ischgl and Neustift, but decreasing in Schönberg and in the province of Tyrol as a whole. As in Schönberg, where only one cable car existed, which was closed down, many of the smaller ski resorts in Tyrol with single cable cars shut down as bigger resorts emerged as a result of fusions between neighbouring smaller resorts. In 1992, a moratorium (cable car directive) was passed by the federal government of Tyrol, prohibiting the development of new ski lifts but allowing the replacement of old installations [16].

Transport capacities increased much more than the numbers of cable cars, as many T-bar lifts were replaced with chair lifts and gondolas. In contrast to surface lifts, transportation by chair lifts and gondolas does not rely on snow cover of the track, so that these cable cars can also be used as shuttles to higher parts of the ski resorts from the valley station, so that often the main ski runs are located at high to medium elevations in the resorts and the connection to the valley station is a single ski track.

The number of overnight stays decreased in Schönberg but increased the three other communities and for the province of Tyrol as a whole. The closing down of the ski lift in Schönberg did not coincide with a decrease in winter overnight stays. The highest increase in winter overnight stays was recorded in Ischgl, which also saw the sharpest increase in transport capacities. Winter overnight stays in Neustift and Galtür are increasing more slowly than in Ischgl. For the province of Tyrol, the growth in winter overnight stays flattens out after 2005, as is the case in Neustift and Galtür. 

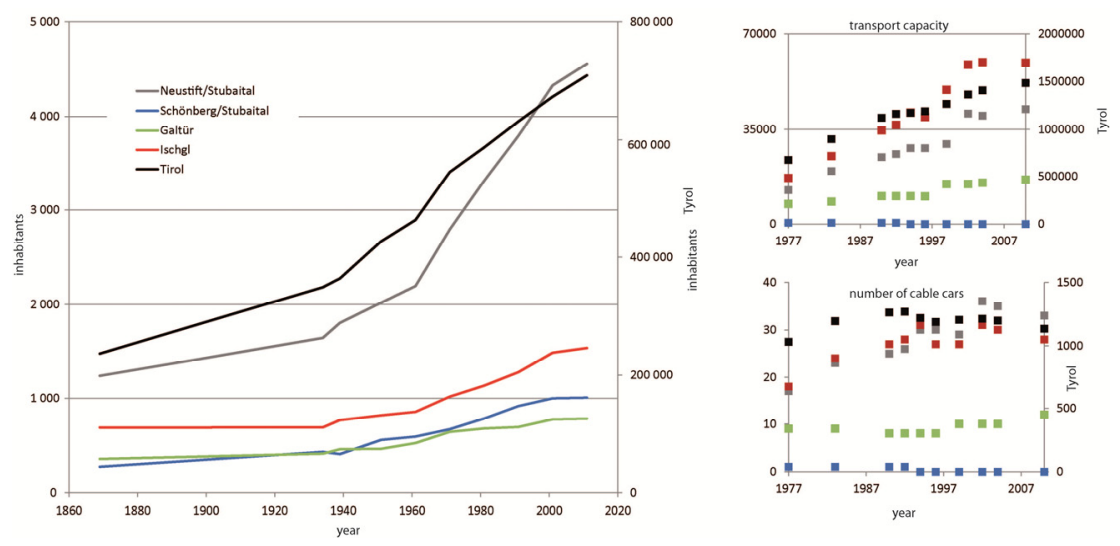

Figure 2: Development of the number of inhabitants, the number of cable cars and the transport capacity of the cable cars in the four communities and for the province of Tyrol.

Summer overnight stays in Tyrol reached a maximum in the late 1980s, exceeding winter overnight stays at the time, but with a decreasing trend since then. In the four communities of the study summer overnight stays have remained approximately at the same level. In Neustift the switch from summer to winter tourism occurred in the mid-1980s, about ten years earlier than for the

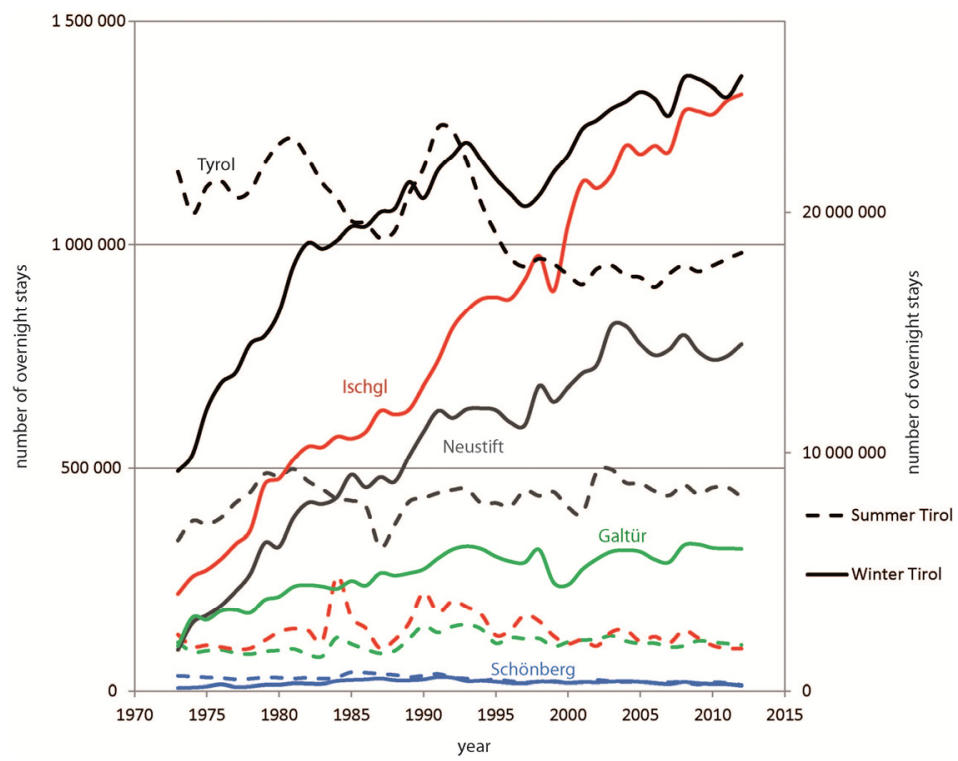

Figure 3: Development of the number of overnight stays for the summer and the winter season in the four communities and for the whole province of Tyrol. 
whole province, in Galtür at the end of the 1970s. In Ischgl, the discrepancies between winter and summer overnight stays are largest. In Schönberg winter and summer converged after an overhang of winter overnight stays in the early years.

\section{Climate and climate change}

Climatic parameters recorded at stations located close to the main altitudes of ski resorts are shown here. Generally, long instrumental meteorological time series are available for a limited number of locations and need careful data homogenization to reflect climatic changes. Within the HISATLP data set, time series of temperature and precipitation have been homogenized. From the available stations, season means of air temperature time series for Obergurgl and Galtür are shown here, together with a pair of one valley and one mountain station in Innsbruck and at the nearby Patscherkofel summit to reflect temperature gradients.

Unfortunately, measuring snow cover is much more complex than measuring temperature in that the presence of an observer is needed. Therefore most records of snow cover are available for valley stations and there are very few places where snow cover and temperature time series are available. Therefore the locations of the specific records presented in these studies differ but have been selected for a climatologically similar setting and thus representative for the ski resorts.

Snow cover records are presented for Obergurgl and Galtür, Brenner and Dresdner Hütte. The calculation of potential snow production times in this study is based not only on daily air temperatures. As evaporation plays an important role for the freezing of the droplets, air humidity has also to be included. From six investigated Tyrolean stations [17], snow production times and their temporal changes are presented for the stations at Obergurgl, Patscherkofel and Kitzbühel, representing typical altitudinal ranges for Tyrolean ski resorts.

\subsection{Temperature}

The mean air temperatures [18] in the summer season (June, July and August) present an increasing trend from the 1970s onwards, but are close to stationary for the winter season (Table 2). As also evident from Figure 4, the temperature variability in winter exceeds the summer oscillations, and the temperature gradients between Patscherkofel summit station and the Innsbruck Valley Station are smaller in winter than in summer.

The long-term temperature lapse rate between Patscherkofel summit station and Innsbruck is $0.4 \pm 0.3^{\circ} \mathrm{C}$ per $100 \mathrm{~m}$ in winter and $0.6 \pm 0.1^{\circ} \mathrm{C}$ per $100 \mathrm{~m}$ in summer for the years 1991 to 2012. Thus temperature differences between different altitude levels are much smaller in winter than in summer, but show higher variability as a result of quite frequently occurring temperature inversions. 


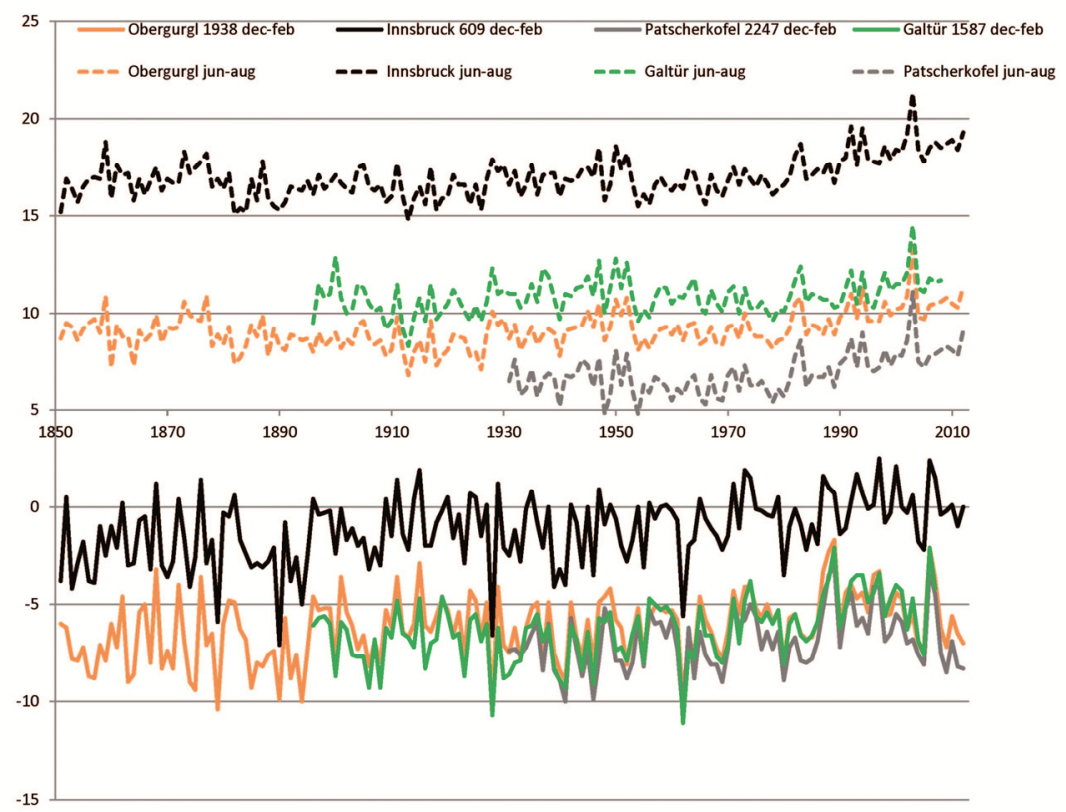

Figure 4: Seasonal air temperature means at the four stations Obergurgl, Innsbruck, Patscherkofel and Galtür.

Table 2: Decadal temperature trends for Obergurgl, Innsbruck, Patscherkofel and Galtür from 1970 onwards.

\begin{tabular}{|l|r|rr|cr|}
\hline Station & $\begin{array}{c}\text { Altitude } \\
\text { m a.sl. }\end{array}$ & \multicolumn{2}{|c|}{ Winter ${ }^{\circ} \mathrm{C}$} & \multicolumn{2}{|c|}{ Summer ${ }^{\circ} \mathrm{C}$} \\
\hline Obergurgl & 1938 & -0.1 & 0.2 & 0.5 & 0.1 \\
\hline Innsbruck & 609 & 0.1 & 0.2 & 0.6 & 0.1 \\
\hline Patscherkofel & 2247 & -0.1 & 0.2 & 0.4 & 0.1 \\
\hline Galtür & 1587 & 0.4 & 0.2 & 0.5 & 0.1 \\
\hline
\end{tabular}

\subsection{Snow height}

Snow height shows a quite high spatial and interannual variability [17], although mean snow height varies only between $42 \mathrm{~cm}$ at the Brenner station and $59 \mathrm{~cm}$ at the Dresdner Hütte. The maximum snow height ranges from $140 \mathrm{~cm}$ at Brenner to $215 \mathrm{~cm}$ at Dresdner Hütte. Figure 5 demonstrates that the high snow heights occur with great variability from year to year without following a general trend and varying from station to station.

The snow heights in Obergurgl are often in a similar magnitude as the ones in Galtür, although the station in Galtür is located $351 \mathrm{~m}$ lower than the one in Obergurgl. This indicates that altitude as a single parameter is not a good predictor for duration or height of snow. 

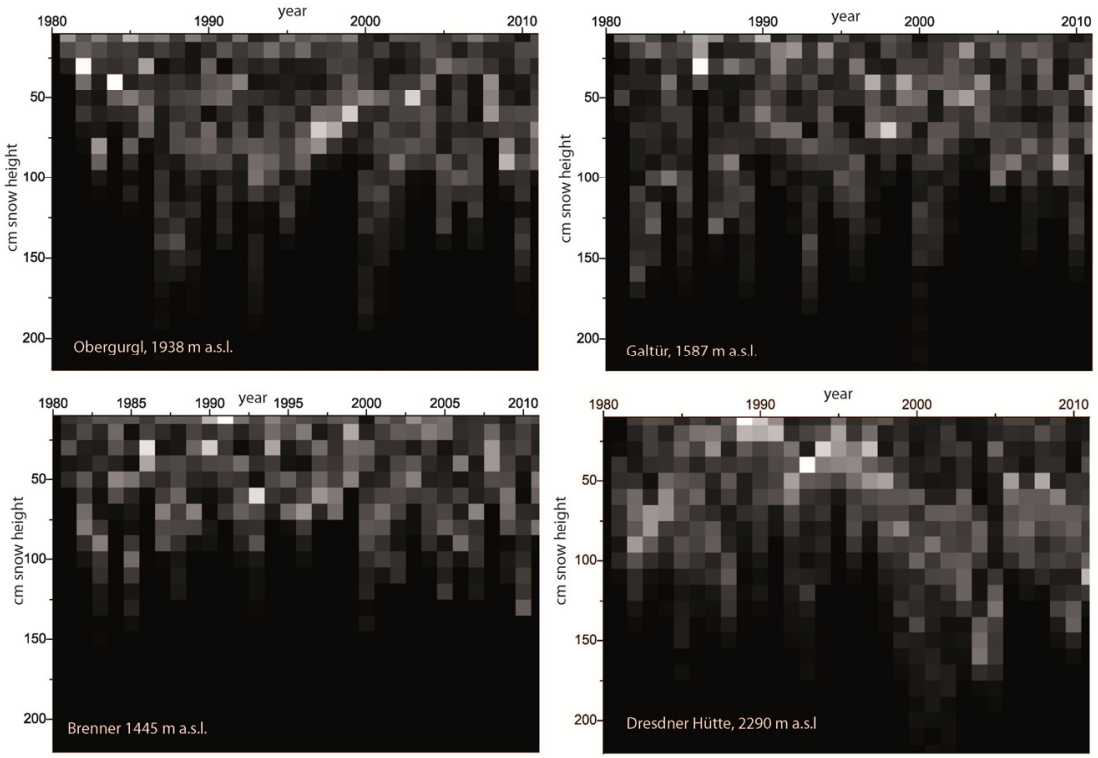

0 days/year

high number of days 70 days/year

Figure 5: Colour-coded absolute frequency (in days per year) of specific snow heights (black: no day of occurrence, white: 70 days of occurrence).

\subsection{Snow production}

Freezing liquid droplets in the air needs energy exchange between the droplets and the air, involving temperature gradients (air colder than droplet) but also evaporation as main drivers. The conditions for snow production at $-2.0^{\circ} \mathrm{C}$ dry air temperature and $90 \%$ relative humidity and $+1.0^{\circ} \mathrm{C}$ dry air temperature and $45 \%$ relative humidity, are similar, both corresponding to a wet bulb temperature of $-2.5^{\circ} \mathrm{C}$. Therefore, neglecting relative humidity and analysing dry air temperatures causes an uncertainty larger than the temperature trend to be expected for the next two decades. The potential snow production time was therefore calculated by Fischer et al. [17] from time series of temperature and relative humidity, which were converted into wet bulb temperatures. Fischer et al. [17] found a limit for snow production at a wet bulb temperature of $-2^{\circ} \mathrm{C}$.

Olefs et al. [18] investigated past changes in snow production days for six climate stations in Tyrol. They did not just include daily mean values, as today snow production often takes place over night, so that at the beginning of the season daily mean conditions are not good indicators of potential snow production times. In the study of Olefs et al. [18], interannual variability of snow production turned out to be high for most periods and most stations, while no statistically significant trend could be derived by applying a Mann Kendall analysis. Few changes in snow production times occurred during the main season, and the percentage of days suitable for snow production is high. 
Snow production times changed most significantly at mid-range altitudes ( 2000 m a.s.1.), with smaller changes at high and low elevations.

For Obergurgl (1953-2007), the potential snow-making days decreased by 22 days per season for Obergurgl, mainly in November (-12 days), and in April (-10 days). During the main season, December to March, the potential snow-making days decreased by only 2 days. Between mid-December and mid-February, the likelihood of snow production days is slightly above $80 \%$. Between winter $2001 / 2002$ and winter $2005 / 2006$, a slightly positive trend in snow production was found.

At Patscherkofel (1948-2007), a positive trend in wet bulb temperatures has been recorded since the $1970 \mathrm{~s}\left(+1.5^{\circ} \mathrm{C}\right)$, resulting in a significant decrease of 43 days/season in the snow-making days, mainly in November (-13 days) and April (-17 days). In the core season between January and late February, the likelihood for snow production is more than $90 \%$.
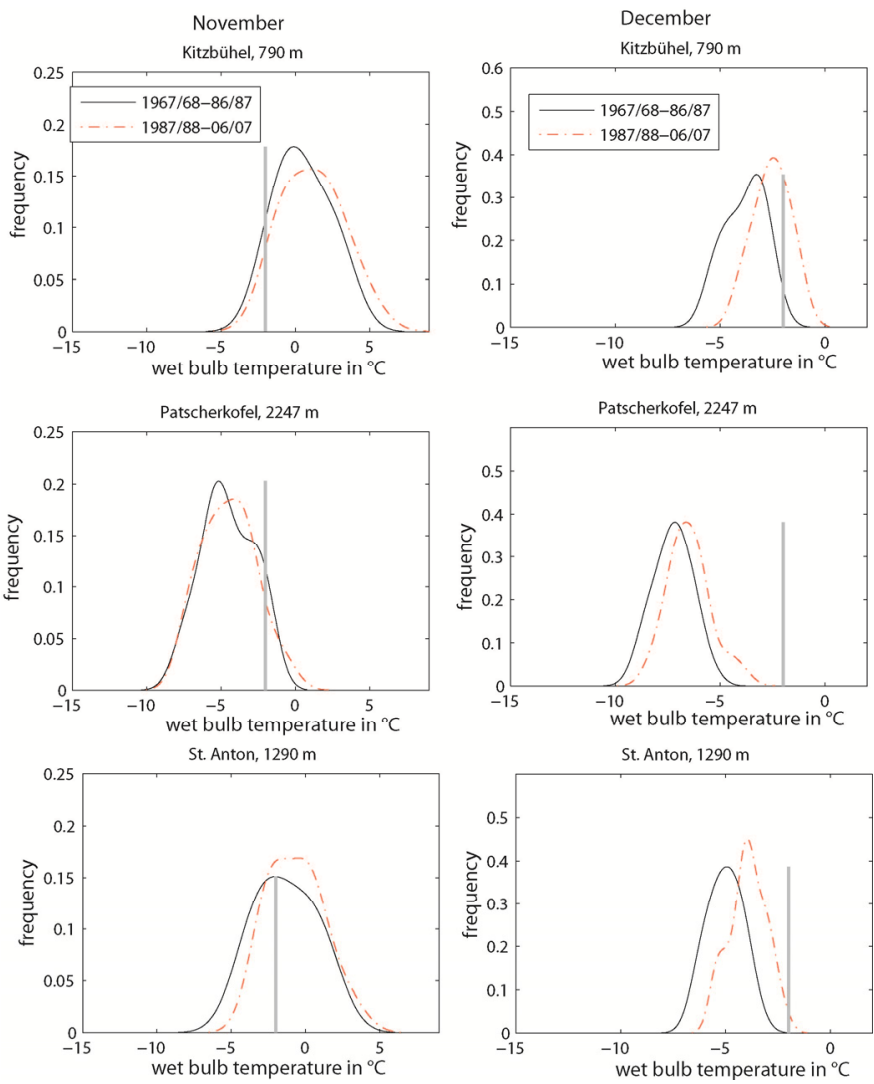

Figure 6: Frequency of wet bulb temperatures for two different periods (1967/68 to $1986 / 87$ and $1987 / 88$ to $2006 / 07$ ) for the months of November and December. The grey bar indicates the threshold temperature for snow production. 
Early in the winter season, the hours when snow production is possible increase rapidly between the beginning of November and the end of December. Figure 6 shows frequency distributions of wet bulb temperatures for these months, with the area left of the grey bar representing times when snow production is possible. At all three stations, enough snow production hours occur in November to ensure piste preparation (3 days of snow making needed). In December, at all three stations, snow production is possible most of the time. Although the two periods shown by the red broken and the black solid line differ by the number of hours, no significant changes occur in terms of reduction of potential snow production times.

\section{Comparison of climatological parameters and overnight stays}

The number of snow days and mean annual snow heights for the stations Brenner and Dresdner Hütte were compared to the number of overnight stays in the communities of Neustift and Schönberg; ditto the snow days in Galtür to the overnight stays in Ischgl. As obvious from the comparison of Figures 3 and 5 , overnight stays increase, whereas snow cover shows no significant trends, and thus no significant correlation between overnight stays and snow cover duration or snow height was found.

Therefore, the growth trends in overnight stays are very likely related to other factors than snow heights or the number of snow days. As the trends in winter temperatures are stationary, there is also no statistical correlation between the increasing numbers of overnight stays and seasonal temperature means.

\section{Comparison of the past to the expected range of future climate change}

The global climate scenarios show a general increase of the mean annual air temperature, but also a high range of variability regarding the quantity of this increase. For the period 2016-2025, temperature increases between about $0.3^{\circ} \mathrm{C}$ and $1.1^{\circ} \mathrm{C}$ have been calculated, for the period 2046 to 2055 , the values range from $0.5^{\circ} \mathrm{C}$ to $2.3^{\circ} \mathrm{C}$ [19]. Even the maximum range of temperature increases is small compared to the observed ranges of seasonal mean temperatures of $7.7^{\circ} \mathrm{C}$ at Patscherkofel and $9.0^{\circ} \mathrm{C}$ in Galtür presented above. From this comparison we can conclude that very likely, apart from seasonal extreme values which can occur as a result of specific weather patterns fairly independently of the climatological mean, every future seasonal mean until 2055 is very likely to have occurred in the past century.

The future scenarios of snow cover extent have been calculated from the changes in precipitation and temperatures. The range of precipitation changes in the winter season is much higher than that for the temperatures. , Given an 
uncertainty range of future winter precipitation for the Alps of $+/-20 \%$, it even remains unclear whether there is an increase or a decrease in precipitation [20]. Together with the variability of future temperature increases, snow cover trends for the Alps for the years until 2050 remain highly uncertain.

Assuming that extremes in every climate are outliers, it can be concluded that we will have already recorded most of the future winter snow cover durations and snow heights in the past, although possibly at different absolute frequencies.

\section{Discussion and conclusions}

The four selected communities are well spread around the Tyrolean average in terms of their proportion of area for ski resorts and they represent different types of communities from peripheral to quite central communities. The growth trends of overnight stays and the dominance of winter overnight stays over summer overnight stays occurred at different times. The comparison with the number of cable cars and the transport capacities shows that the increasing number of overnight stays coincides with increasing transportation capacity, notwithstanding the unclear causality. Ischgl and Galtür are basically located in the same climatological setting and have experienced very different developments in overnight stays.

Taking into account that snow production begun in the early 1990s and today covers about $70 \%$ of the total area of ski runs, it is no wonder that the overnight stays do not appear to depend on snow cover. The analysis indicates that within the last 50 years snow production did indeed change, but not in such a way that one could expect significant changes in the main season in the near future.

Past climate variability exceeds the scenarios of climate change for the next decades.

To sum up, a limitation of the still increasing winter tourism will very likely not be caused by climatic changes but by other macroscale forcings. As the effect of the cable car directive demonstrates, policy can play an important role in shaping future possibilities and in dealing with local resources. Sustainable development of winter tourism thus is more closely related to the clever use of local resources, such as settlement areas and business parks or water and energy consumption, than to climate change.

\section{Acknowledgements}

The Interreg project 3P CLIM is acknowledged for providing the data on snow cover, the HISTALP projects (www.zamg.ac.at\HISTALP) for providing the temperature time series. The data on the number of inhabitants, overnight stays, number of cable cars and transport capacities was provided by the Federal Government of Tyrol, Statistics Dept. and compiled from data of the regional statistics of the Sports Dept., and TIRIS and by Statistik Austria. 


\section{References}

[1] Statistik Austria, 2012 http://www.statistik.at/

[2] Laimer \& Ostertag-Sydler, Tourismus-Satellitenkonto, Statistik Austria, http:/www.statistik.gv.at/web_de/statistiken/tourismus/tourismussatellitenkonto/index.html

[3] Scott, D. \& Lemieux, C., Weather and climate information for tourism. Procedia Environmental Sciences, 1, pp. 146-183, 2010.

[4] Butler, R. W., Sustainable tourism: A state-of-the-art review, Tourism Geographies: An International Journal of Tourism Space, Place and Environment, 1(1), pp. 7-25, 1999. DOI: 10.1080/14616689908721291.

[5] World Tourism Organization, Sustainable Tourism Development: Guide for Local Planners. Madrid: WTO, 1993.

[6] Foerster, H. v., Understanding, Springer, 2003.

[7] Scott, D., Why sustainable tourism must address climate change, Journal of Sustainable Tourism, 19(1), pp. 17-34, 2011. DOI: 10.1080/09669582.2010.539694.

[8] Weaver D., Can sustainable tourism survive climate change? Journal of Sustainable Tourism, 19(1), pp. 5-15, 2011. DOI: $10.1080 / 09669582.2010 .536242$.

[9] Abegg, B., Agrawala, S., Crick, F., \& de Montfalcon, A., Climate change impacts and adaptation in winter tourism. In S. Agrawala (Ed.), Climate change in the European Alps. Adapting winter tourism and natural hazards management, pp. 25-60, Paris: OECD, 2007.

[10] Scott, D., McBoyle, G., Minogue, A.\& Mills, B., Climate Change and the Sustainability of Ski-based Tourism in Eastern North America: A Reassessment, Journal of Sustainable Tourism, 14(4), pp. 376-398, 2006.

[11] Steiger. R. \& Stötter. J., Climate Change Impact Assessment of Ski Tourism in Tyrol, Tourism Geographies: An International Journal of Tourism Space, Place and Environment, 15(4), pp. 577-600, 2013. DOI: 10.1080/14616688.2012.762539.

[12] Müller, H., Entwicklungsszenarien für den Alpenraum. ed. Egger, R. \& Herdin T., Tourismus: Herausforderung: Zukunft, Wissenschaftliche Schriftenreihe des Zentrums für Tourismusforschung - Salzburg, 1, pp. 365-376, 2007.

[13] Steiger, R., Scenarios for skiing tourism in Austria: integrating demographics with an analysis of climate change, Journal of Sustainable Tourism, 20(6), pp. 867-882, 2012, DOI: 10.1080/09669582.2012.680464.

[14] Gössling, S., Hall, C. M., Ekström, F., Engeset, A. B. \& Aall, C., Transition management: a tool for implementing sustainable tourism scenarios? Journal of Sustainable Tourism, 20(6), 899-916, 2012. DOI: 10.1080/09669582.2012.699062.

[15] Moriarty, J. P., Theorising scenario analysis to improve future perspective planning in tourism, Journal of Sustainable Tourism, 20(6), pp. 779-800, 2012. DOI: 10.1080/09669582.2012.673619. 
[16] Amt der Tiroler Landesregierung/Abt. 1c - Landesplanung, Seilbahngrundsätze des Landes Tirol mit Festlegung der Grenzen der Schigebiete in den Tourismusintensivgebieten, 1992.

[17] Fischer, A., Olefs, M. \& Abermann, J., Glaciers, snow and ski tourism in Austria's changing climate. Annals of Glaciology, 52(58), pp. 89-96, 2011.

[18] Olefs, M., Fischer, A. \& Lang, J., Boundary conditions for artificial snow production in the Austrian Alps, Journal of Applied Meteorology and Climatology, 49, pp. 1096-1113, 2010.

[19] Auer, I., Böhm, R., Jurkovic, A., Lipa, W., Orlik, A., Potzmann, R., Schöner, W., Ungersböck, M., Matulla, C., Briffa, K., Jones, P.D., Efthymiadis, D., Brunetti, M., Nanni, T., Maugeri, M., Mercalli, L., Mestre O., Moisselin J.-M., Begert M., Müller-Westermeier G., Kveton V., Bochnicek O., Stastny P., Lapin, M., Szalai, S., Szentimrey, T., Cegnar, T., Dolinar, M., Gajic-Capka, M., Zaninovic, K., Majstorovic, Z. \& Nieplova, E., HISTALP - Historical instrumental climatological surface time series of the greater Alpine region 1760-2003. International Journal of Climatology, 27, 17-46, 2007.

[20] Kirtman, B., Power, S.B., Adedoyin, J.A., Boer, G.J., Bojariu, R., Camilloni, I., Doblas-Reyes, F.J., Fiore, A.M., Kimoto, M., Meehl, G.A., Prather, M., Sarr, A., Schär, C., Sutton, R., van Oldenborgh, G.J., Vecchi, G. \& Wang, H.J., Near-term Climate Change: Projections and Predictability. In: Climate Change 2013: The Physical Science Basis. Contribution of Working Group I to the Fifth Assessment Report of the IPCC, ed. Stocker, T.F., Qin, D., Plattner, G.-K., Tignor, M., Allen, S.K., Boschung, J., Nauels, A., Xia, Y., Bex, V. \& Midgley, P.M., Cambridge University Press, Cambridge, United Kingdom and New York, NY, USA, 2013.

[21] Christensen, J.H., Hewitson, B., Busuioc, A., Chen, A., Gao, X., Held, I., Jones, R., Kolli, R.K., Kwon, W.-T. , Laprise, R., Magaña Rueda, V., Mearns, L., Menéndez, C.G., Räisänen, J., Rinke, A., Sarr, A. \& Whetton, P., Regional Climate Projections. In: Climate Change 2007: The Physical Science Basis. Contribution of Working Group I to the Fourth Assessment Report of the IPCC, ed. Solomon, S., Qin, D., Manning, M., Chen, Z., Marquis, M., Averyt, K.B., Tignor, M. \& Miller, H.L., Cambridge University Press, Cambridge, UK and New York, NY, USA, 2007. 